\title{
Work Performance of A Village Head: Investigating The Role of Job Satisfaction, Workload, and Work Stress
}

\author{
Dewi Prihatini \\ Department of Management \\ Faculty of Economics and Business \\ University of Jember \\ Jember, Indonesia \\ dewiprihatini@unej.ac.id

\begin{abstract}
Are work performance of a village head determined by job satisfaction, workload, and job stress? Using Structural Equation Model (SEM) method, several hypothesis were investigated in this study. Population of this study is all 226 Village Head in Jember Regency with sample selected as of 127 respondents. Data were collected by a survey using questionnaire and interview. Findings offer support the first two hypothesis that workload and job stress have significantly negative effect to job satisfaction. However workload, job stress and work satisfaction have no significant effect toward work performance of village head in Jember Regency. This is an anomaly result compared to the existing theory and empirical studies.
\end{abstract}

Ade Karina

Department of Management

Faculty of Economics and Business

University of Jember

Jember, Indonesia

\author{
Sri Wahyu Lely Hanna Setyanti \\ Department of Management \\ Faculty of Economics and Business \\ University of Jember \\ Jember, Indonesia
}

Keywords—work performance, job satisfaction, village head

\section{INTRODUCTION}

Act No. 6 Year 2014 about village is implemented within the framework of regional autonomy. However, a number of opportunities stipulated in the Village Act does not automatically make the governance and rural development can run smoothly, because the implementation stage will be faced a number of obstacles, both external and internal factors and one of them is the quality of human resources. The ability of the village officials and the village council in development planning, budget management and government management becomes an important key in improving services to the community of the village.

The village head is the supreme leader of the government in the village. The task of the village head stated in the Article 26 paragraph 1 of the Village Constitution are to organize the village administration, carry out rural development, community development, and community empowerment. To accomplish these tasks, a village head need sufficient work experience to enhance the knowledge, skill, and dexterity in the service.

Changes in the work rules and the work demands that are part of the implementation of the Village Act can lead to a counterproductive situation as a pressing for the village head and village officials. If the village head, as an individual or a leader, cannot immediately adapt to the changing of the demands, it can be perceived this as pressure that would threaten him.

One of the changes in the demands of work of the government apparatus is the fulfillment of the community satisfaction of services they provide. Community satisfaction may not be achieved if the government apparatus as a service provider is not satified in the work [1][2] . Job satisfaction can be obtained by gaining praise for the work, placement, treatment, equipment, and a good working environment atmosphere.

An overview of the quality of service to the public by government officials including the village head and the village apparatus still has not shown as the expected results. This is reinforced by the findings of the field that the problems experienced by the village government still continues to grow each year. The phenomenon of an increasing number of village heads in Jember Regency who stumble legal problems even after the issuance of Law Village in 2014 is a reality that should be sought immediately root of the problem and also the solution. These problems directly and indirectly affect the quality of work as the head of the village administration. As we know, the issuance of new Village Legislation has a logical consequence that increase the workload of the village heads. Increasing workload will be simultaneous with the increase in work stress level affects job satisfaction of village head [3]. Job satisfaction will ultimately have an impact on the performance of each village head in providing services in the village. Government of Jember Regency has sought to improve the job satisfaction of village heads in running village government and one of them is to provide compensation in the form of a steady income. Job satisfaction [4] is considered as "one of the most complex areas facing today's managers when it comes to managing their employees". It is about the way employees feel about his or her job. It can be simplified that 
job satisfaction is a feeling of support or no support within employee related to work and the condition itself [5]. Job satisfaction has frequently demonstrated direct and indirect impact on the performance of the employee [6].

The study has something interested to do in order to test job satisfaction of the village heads in Jember Regency and its important role in improving the level of their work performance. If the village heads feel satisfy in their work, then the increasing workload and job stress no longer be a major problem in running daily tasks. Study of job satisfaction becomes crucial in recent years because of its potentials' impacts on the work performance [7]. As an academic concept, many researches give wide attentions from several field studies such as management, social, and psychology. This paper was able to justify the antecedents and outcomes of job satisfaction.

\section{METHODOLOGY}

This research is an explanatory research that describes causal relationships and examined the association between the variables workload, work stress, job satisfaction and work performance of the village head. The population in this study were all village heads in Jember Regency as many as 226 people. The research sample is determined using a proportional stratified random sampling technique based on their academic background with a total sample of 145 village heads.

This paper presents a field survey. The data collection method of primary data used questionnaire instrument. They have previously been given an explanation of the points in the questionnaire in order to more easily understand the intent of the questions for avoiding giving a wrong answer. Of the 145 questionnaires distributed were only 127 completed and deserves to be analyzed.

Then, the data is processed and presented using descriptive statistical analysis. To be able to answer the research questions and hypothesis testing, it was used inferential statistics approach. The statistical method used to test the hypothesis in this study was a multivariate technique known as Structural Equation Modeling (SEM). SEM has the ability to examine the relationship between complex variables and to obtain an overall picture of the overall models as shown in Fig. 1.

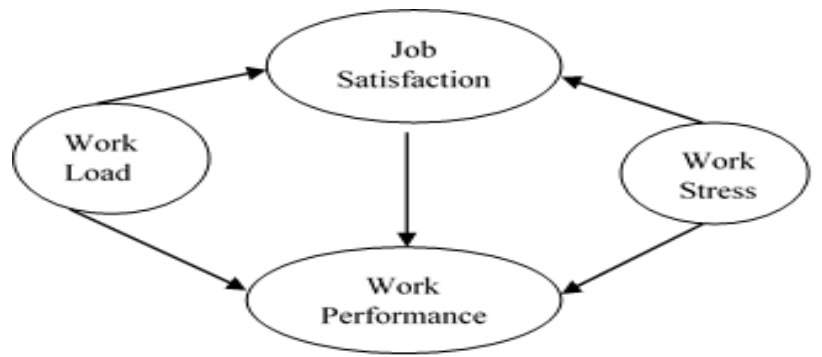

Fig 1. Conceptual Framework of Research

\section{RESULT AND DISCUSSION}

A village head must have graduated from Junior High School (SMP) as minimum requirement because the educational background have a crucial role in supporting village head run their duties and responsibilities. The results of descriptive statistical analysis based on respondents' answers related to research variables that workload, job stress, job satisfaction and performance are classified according to the village head educational background are shown in the following table.

TABLE 1. SUMMARY OF THE AVERAGE RESPONDENTS' ANSWER OF RESEARCH VARIABLES BASED ON EDUCATIONAL BACKGROUND

Variable

Average Respondents' Answer

\begin{tabular}{|c|c|c|c|}
\hline & \\
\hline & $\begin{array}{c}\text { Junior high } \\
\text { School }\end{array}$ & $\begin{array}{c}\text { Senior High } \\
\text { School }\end{array}$ & $\begin{array}{c}\text { Bachelor } \\
\text { Degree }\end{array}$ \\
\hline Work Load & 4.2 & 4.1 & 3.8 \\
\hline Job Stress & 2.5 & 2.3 & 2.4 \\
\hline Job Satisfaction & 3.5 & 3.5 & 3.6 \\
\hline Work Performance & 3.6 & 3.7 & 3.8 \\
\hline
\end{tabular}

Results of descriptive statistical analysis in Table 1 indicate that on average workload of a village head is felt most heavy by the village head who have junior high school compared to senior high school and bachelor degree. In terms of work stress variables, it has the same figure that the village head with the educational background of junior high school experiencing work stress is very high, higher than senior high school and bachelor's graduates. The different result is shown in job satisfaction variables. The village heads with bachelor's graduates have the highest job satisfaction. Furthermore, the village heads who have bachelor's educational background have a better performance than educational background compared to junior and senior high school graduates.

The other results of descriptive analysis showed that the village heads have been familiar with their workloads in terms of targets to be achieved and time period of achievement. The psychological experience of the village heads is also very helpful in completing the work [8]. However, most of the village heads understand that their job is potentially causing stress. As the village head, they manage the budget of the village so that if there is a mismanagement in the use of the budget then the village heads should be held accountable by law. In terms of their salary, only about $20 \%$ were satified while most of them were said fairly $(41 \%)$ and the rest were unsatisfied. They argue that the village head received salaries are only slightly larger than the regional minimum wage but they have very high responsibilities in developing areas and communities as well. The dependent variable, work performance, indicated that the village heads have a good enough work performance.

Stages of the inferential statistical analysis began with Validity and Reliability Test of the data. Both tests were employed to ensure that the data obtained viabled used in subsequent analyzes. The results across the indicators were declared valid and reliable at the level of significance 5 percent $(\alpha=0.05)$.

The next stage was the analysis of Structural Equation Model (SEM) which has the ability to test structural models simultaneously and efficiently when compared to other 
multivariate techniques. Software used for data processing was SPSS AMOS 20 as shown in Fig. 2.

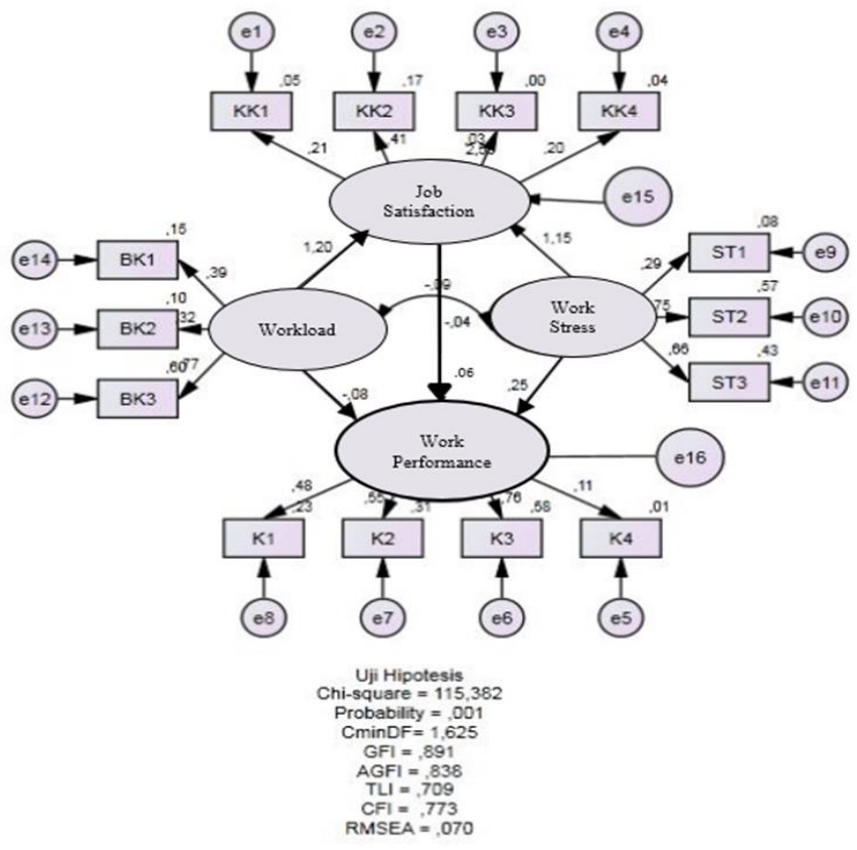

Fig 2. Analysis of SEM

The value of each goodness-of-fit index further confirmed that level of fitness model well enough. Table 2 shows the results.

TABLE 2. VALUE OF GOODNESS-OF-FIT

\begin{tabular}{|l|l|l|l|l|}
\hline No & & Criteria & Value & Status \\
\hline $\mathbf{1}$ & Chi-Square & $\begin{array}{r}\leq 129,838 ; \text { df } 110 ; \\
\text { level of sig } 5 \%\end{array}$ & 115,382 & Good Fit \\
\hline $\mathbf{2}$ & Probability & $\geq 0,05$ & 0,01 & Good Fit \\
\hline $\mathbf{3}$ & CMIN/DF & $\leq 2$ & 1,625, & Good Fit \\
\hline $\mathbf{4}$ & RMSEA & $\leq 0,08$ & 0,070 & Good Fit \\
\hline $\mathbf{5}$ & GFI & $\geq 0,90$ & 0,891 & Marginal Fit \\
\hline $\mathbf{6}$ & AGFI & $\geq 0,90$ & 0,773 & Marginal Fit \\
\hline $\mathbf{7}$ & TLI & $\geq 0,90$ & 0,709 & Marginal Fit \\
\hline $\mathbf{8}$ & CFI & $\geq 0,90$ & 0,773 & Marginal Fit \\
\hline
\end{tabular}

The hypothesis test is based on analysis of the regression value from the research data which processed using SEM analysis as shown in the Table 3. Hypothesis testing was done by analyzing the C.R. and P value of the calculation results of SEM analysis. The hypothesis is rejected if does not meet the required statistical limits, i.e. above 1.96 for the value of C.R. and below 0.05 for the value of $P$.
TABLE 3 RESULTS OF SEM ANALYSIS CALCULATION

\begin{tabular}{|c|l|l|c|c|c|}
\hline \multicolumn{1}{|c|}{} & & C.R. & P & Description \\
\hline $\begin{array}{c}\text { Job } \\
\text { satisfaction }\end{array}$ & $\longleftarrow$ & Workload & 2.033 & 0.042 & Accepted \\
\hline $\begin{array}{c}\text { Job } \\
\text { satisfaction }\end{array}$ & $\longleftarrow$ & Work Stress & 2.063 & 0.039 & Accepted \\
\hline Performance & $\longleftarrow$ & Workload & -0.405 & 0.686 & Rejected \\
\hline Performance & $\longleftarrow$ & Work Stress & 0.740 & 0.459 & Rejected \\
\hline Performance & $\longleftarrow$ & $\begin{array}{c}\text { Job } \\
\text { Satisfaction }\end{array}$ & -0.288 & 0.773 & Rejected \\
\hline
\end{tabular}

The results of statistical method calculation with SEM Analysis showed that from five hypothesis submitted only two hypotheses were not rejected while three other hypothesis were rejected. These findings indicated that the level of workload and job stress would significantly have negative effects to the level of job satisfaction of the village head [9]. The higher of workload and job stress would lead to the village head more unsatisfied with his work, and vice versa.

The detailed results of the research hypothesis testing are discussed in stages in accordance with the hypothesis that has been proposed and displayed in Table 4 as belows.

\section{TABLE 4. SUMMARY OF RESULTS OF RESEARCH HYPOTHESIS} TESTING

\begin{tabular}{|c|l|c|}
\hline H1 & $\begin{array}{l}\text { Horkload has significantly negative effect } \\
\text { toward job satisfaction of village head }\end{array}$ & Test Results \\
\hline H2 & $\begin{array}{l}\text { Job stress has significantly negative effect toward } \\
\text { job satisfaction of village head }\end{array}$ & Not Rejected \\
\hline H3 & $\begin{array}{l}\text { Workload has significantly negative effect } \\
\text { toward work perfromance of village head }\end{array}$ & Rejected \\
\hline H4 & $\begin{array}{l}\text { Job stress has significantly negative effect toward } \\
\text { work performance of village head }\end{array}$ & Rejected \\
\hline H5 & $\begin{array}{l}\text { Job satisfaction has positive and significant effect } \\
\text { to the work performance of the Village Head }\end{array}$ & Rejected \\
\hline
\end{tabular}

The different findings of SEM analysis showed that workload, job stress, and job satisfaction are not good measurement tools to assess the performance of a village head. Thus the good or bad of the village head performance cannot be determined from the level of workload, job stress, and the satisfaction felt by the village head. Village head performance is determined by other factors which are not analyzed in this study. The results of this analysis also shows that job satisfaction does not play role as well to strengthen the influence of the workload and job stress on the performance of the village head. This findings is an antithesis of what [10] and [11] found in their study.

What makes the work load has negatively affect on job satisfaction of the village head may a reward and punishment system not properly applied. Everything that happens to the citizens is the responsibility of the village head. The work load of the village head will increase along with the number of 
demands from the community. Implementation of the system of reward and punishment is not executed well to make work loads done on the village head into linearly with an increase in salary or benefits received. The increasing work load of the village head will also be exhausting, time and thought the village head. Workload is distress experienced by employees in relation to their occupation [12]. The village head also feels stressed while performing tasks and solving various problems that exist in the village. Finding of the study shows that there is a bit of a village head who had conflicts with colleagues or village apparatus. When the village head has a lot of workload and job stress it will have a negative impact on their job satisfaction.

Performance is a recapitulation of the acquired person for the job functions performed during a specific time period [13]. Government of Jember Regency has not implemented a comprehensive indicator to measure the performance of a village head. Until now, assessment of a village head performance is based only on the number of budget absorption per year. This condition further explain why the research findings about village head performance is not significantly affected by the workload and job stress. Job satisfaction is also not a good indicator for measuring the performance of a village head because the performance of the village head could not be distinguished between the village head of who satisfied or dissatisfied.

Government of Jember Regency has actually been making efforts to improve the job satisfaction of village heads by providing compensation in the form of fix salary. Previously, monthly income of a village head has only been taken from yields of village lands. The amount of allowances and operational managed by the village head is not the same but based on the size of the financial aid budget villages which are based on some indicators beyond the performance of the village head in accordance with the legislation, such as area covered, total populations, number of poor households, and index of difficulty geography in each region. However, this basis for determining financial aid budget has not been shown significantly increasing the village head performance. The amount of village budget and benefits managed by the village head will not automatically increase even if they performing very well to improve welfare of its citizens. Some village heads instead there who think if they succeed in reducing the number of poor in the region, the Village Fund budget that will be accepted will also be reduced. This assumption makes the village head performance becomes less than the target. This condition indicates that the issue of improving the performance of the village head has become a classic problem that needs serious attention and further study of the various factors that can increase the performance of a village head.

\section{CONCLUSION}

First, workload and job stress has a negative and significant effect on job satisfaction. The village head would be satisfied if the tasks that must be carried as a village head did not feel as a burden. The village head also will be satisfied if they can minimize job stress as pressure experienced in completing the responsibility of leading the village.
Second, Workload, job stress, and job satisfaction do not have significant effect on the performance of the village head because until now the indicators of performance appraisal of village heads in Jember Regency is based only on the level of budget absorption per year.

Third, job satisfaction in this study was not able to give an clearer interpretation about the relationship between the variables workload and job stress and the performance of the village head.

Based on the results of the study conducted on the performance of the village head in Jember Regency, it can be offered several suggestions as follows:

Local Government is advised to implement rewards and punishments system which transparent so that the duties and responsibilities of village heads are not perceived as burdensome due to reward received very satisfying them. Work stress also will not be felt even though a lot of work to be done by the village head; Local Government should evaluate policies related to payroll system of village head in Jember Regency. Basic salary payment for village heads as currently applied could have opposing impacts to the performance of the village head; Local Government need to establish measurable indicators and clear to measure the work performance of the village head and not only on the level of approval of the village budget; The other researchers are expected to conduct advanced research related to the performance of the village head by adding other variables and designing more comprehensive research; Data collection method should be combined between distribution of questionnaires and interviews to ensure that respondents truly understand the contents of the questionnaire.

\section{ACKNOWLEDGEMENT}

This research work has been supported in partial by the Local Goverment of Jember Regency especially all selected village head for their positive contributions during the data collection. Special thanks to Mahardhika for technical assistanship.

\section{REFERENCES}

[1] P. Trivellas, P. Reklitis, and C. Platis, "The Effect of Job Related Stress on Employees' Satisfaction: A Survey in Health Care," Procedia - Soc. Behav. Sci., vol. 73, no. 0, pp. 718-726, 2013.

[2] R. C. Nabirye, K. C. Brown, E. R. Pryor, and E. H. Maples, "Occupational stress, job satisfaction and job performance among hospital nurses in Kampala, Uganda," J. Nurs. Manag., vol. 19, no. 6, pp. 760-768, 2011.

[3] V. M. Lea, S. A. Corlett, and R. M. Rodgers, "Workload and its impact on community pharmacists' job satisfaction and stress: A review of the literature," International Journal of Pharmacy Practice, vol. 20, no. 4. pp. 259-271, 2012.

[4] B. Aziri, "JOB SATISFACTION: A LITERATURE REVIEW," Manag. Res. Pract., vol. 3, no. 4, pp. 77-86, 2011.

[5] Y. Zhu, “A review of job satisfaction,” Asian Social Science, vol. 9, no. 1. pp. 293-298, 2012.

[6] E. R. Thompson and F. T. T. Phua, "A Brief Index of Affective Job Satisfaction,” Gr. Organ. Manag., vol. 37, no. 3, pp. 275-307, 2012.

[7] C. Dormann and D. Zapf, "Job satisfaction: A meta-analysis of stabilities," J. Organ. Behav., vol. 22, no. 5, pp. 483-504, 2001. 
[8] J. L. Szalma, "Individual differences in performance, workload, and stress in sustained attention: Optimism and pessimism," Pers. Individ. Dif., vol. 47, no. 5, pp. 444-451, 2009.

[9] M. Mansoor, S. Fida, S. Nasir, and A. Zubair, "The Impact of Job Stress on Employee Job Satisfaction A Study on Telecommunication Sector of Pakistan,” J. Bus. Stud. Q., vol. 2, no. 3, pp. 50-56, 2011.

[10] C. N. C. Dewi, I. W. Bagia, and G. P. A. J. Susila, "Pengaruh Stres Kerja Dan Kepuasan Kerja Terhadap Kinerja Karyawan Pada Bagian Tenaga Penjualan UD Surya Raditya Negara," e-Journal Bisma Univ. Pendidik. Ganesha Jur. Manaj., vol. 2, 2014.

[11] E. L. Hauck, L. A. Snyder, and L.-E. Cox-Fuenzalida, "Workload
Variability and Social Support: Effects on Stress and Performance," Curr. Psychol., vol. 27, no. 2, pp. 112-125, 2008.

[12] J. Aziz, W. Ejaz, A. R. Jaffari, S. N. Raza, S. S. H. Shah, and I. Ul-Haq, "Workload and Performance of Employees," Interdiscip. J. Contemp. Res. Bus., vol. 3, no. 5, pp. 256-267, 2011.

[13] S. Sonnentag and M. Frese, "Performance concepts and performance theory," Psychol. Manag. Individ. Perform., pp. 3-25, 2002. 